\title{
Surhan-2012: A Novel High Yielding, Insect Resistant, and High Oil Content Canola Variety Released for General Cultivation in the Sindh Province
}

\section{Mohammad Aquil Siddiqui ${ }^{1 *}$, Muhammad Mahran Aslam ${ }^{1}$, Mahboob Ali Sial', Nighat Seema Soomro', Muhammad Tahir Khan ${ }^{1}$, Shafquat Yasmeen ${ }^{1}$, Shumaila Sial ${ }^{2}$ and Imtiaz Ahmad Khan ${ }^{1}$}

${ }^{1}$ Nuclear Institute of Agriculture Tando Jam, Sindh, Pakistan; ${ }^{2}$ Institute of Plant Sciences, University of Sindh, Jamshoro, Pakistan.

Abstract | Genetic variability is a prerequisite for any effective breeding program. Surhan-2012 (R00125/14) is the mutant line that developed through mutation breeding (Gamma radiation) from Rainbow parent. Initially, the promising mutant line was selected from mutant population and advanced homozygous mutant progenies during 2004-05 for yield evaluation in zonal varietal trials and the national uniform rapeseed yield trials (NURYT). The resultant variety exhibited the highest seed yield $\left(2826 \mathrm{~kg} \mathrm{ha}^{-1}\right)$ in NURYT compared to other contesting advanced genotypes during 2008-09. Surhan-2012 was performed better for seed yield (1460.8 $\left.\mathrm{kg} \mathrm{ha}^{-1}\right)$ as compared to parent genotype $(800 \mathrm{~kg} / \mathrm{ha}$ seed yield) in advanced station yield trials. Surhan-2012 produced higher seed yield $(1818 \mathrm{~kg} / \mathrm{ha})$ than local check varieties $(1457$ $\mathrm{kgha}^{-1}$ ) in NURYT during 2007-08 and similar trend was observed during 2008-09. The oil quality of Surhan-2012 was also determined. The mutated variety showed $9.7 \%$ increase in its oil content and novel fatty acid profile which was comparatively higher than the commercial check variety. It was also tolerant against insect pest and diseases including Alternaria blight, powdery mildew, downy mildew and white rust. The agronomic study suggested that this mutant stain (R00-125/14) best fits in the existing cropping system and agronomic package of technology. Surhan-2012 is a first canola mutant variety developed through the induced mutagenesis (gamma irradiations), released for general cultivation practices in the province of Sindh.

Received | July 30, 2021; Accepted | September 29, 2021; Published | December 09, 2021

*Correspondence | Mohammad Aquil Siddiqui, Nuclear Institute of Agriculture Tando Jam, Sindh, Pakistan; Email: siddiqui_aquil@yahoo. com

Citation | Siddiqui, M.A., M.M. Aslam, M.A. Sial, N.S. Soomro, M.T. Khan, S. Yasmeen, S. Sial and I.A. Khan. 2021. Surhan-2012: A novel high yielding, insect resistant, and high oil content canola variety released for general cultivation in the Sindh Province. Pakistan Journal of Agricultural Research, 34(4): 837-845.

DOI | https://dx.doi.org/10.17582/journal.pjar/2021/34.4.837.845

Keywords | Canola, Surhan-2012, Mutation breeding, Fatty acid profiling, Agronomy packages and yield

\section{Introduction}

A rid and semi-arid sections of the third world nations have been facing shortage in their edible oil reserves and imports a large quantity of edible oil every year to fulfill country's demand (Mustafa et al., 2017). There is a great potential of enhancing the canola yield for under developed countries to reduce the gap between consumption and indigenous edible oil production (Onemli, 2014) The edible oil extracted from the seeds of various oil seed crops also display great nutritious and economic value (Mahmood et al., 2019). The vegetable oil composition, fatty acid profiling and nutritional varies variety to variety and plant species (Onemli, 2014; von Hanstein et al., 2020). In the current scenario researchers try to explore the species with good oil content and better fatty acid compositions from the exiting wild germplasm with 
broad adaptability. The wide genetic variation and genetic pool is necessary for scientists to develop new cultivars with genetically improving oil contents, and novel fatty acid (Mustafa et al., 2017; Mahmood et al., 2019). Various Breeding approaches used to modify the plant architecture for the improvement of plant seed yield, oil contents and fatty acid compositions especially low erucic acid and glucosinolates. These are the important factor to improve the nutritional value of new commercial cultivars (Abbadi and Leckband, 2011).

The high yield potential is the major ultimate goal in the present era because world population is increasing geometrically (Abbadi and Leckband, 2011). Induced mutations have been accepted as useful tool in a plant-breeding programme. One of the most important role of mutation breeding is the creation of genetic variability for quantitative traits in various crop plants. The variability, thus created, enhances the chance for selection of new genotypes with desired characteristics.

In Pakistan, the cultivated varieties evolved through direct introduction or selection from exotic germplasm. The exotic germplasm has always been a danger as it may easily become susceptible to local pests. Similarly, the existing varieties losing canola quality characteristics and yield potential due to contamination and out-crossing. Therefore, it is essentially required to develop high yielding canola varieties to overcome the food security problem and replace the existing low yielding varieties. Moreover, the development of new verities can overcome the gap between consumption and production of edible oil which is still widening due boosting population pressure and challenges unsuitable verities cultivation (Hatzig et al., 2018). The commercial release variety (Surhan-2012) has been significantly contributed best performance to overall production in the country and is now considered as a bench mark for oil and seed yield in Pakistan (Mustafa et al., 2017; Mahmood et al., 2019; Viana et al., 2019). In this context, selection and consequently development canola mutant variety (Surhan-2012) that has been registered in 2013 for commercial cultivation in Sindh province of Pakistan. This variety possesses good agronomic characters when compared with locally adapted cultivars.

\section{Materials and Methods}

The variety (Surhan-2012) was developed through in- duced mutation at the dose of $1250 \mathrm{~Gy}$ from cv. Rainbow and selected through mutant selection at Nuclear Institute of Agriculture, Tandojam, Sindh, Pakistan. Homozygous progenies of mutant selection as serial number R00125/14 were bulked during 2004-05 for seed yield evaluation. Its performance was evaluated in different trials such as station yield trial, zonal trial and National Uniform Rapeseed Yield Trials. Similarly, different botanical characteristics were also recorded according to FSC\&RD, Islamabad (Table 1).

\section{Evaluation and yield testing}

In station yield trials during 2008-09, yield of R00125/14 was compared with parent (Rainbow). The high yield promising line (R00-125/14) was then further evaluated at zonal yield trial of rapeseed at seven locations viz. Tando Jam, Sheikh Burkhio, Tando Adam, Sanghar, Khipro Shaikh Burkhio and Badin during 2007-08 and NURYT at eight locations during 2007-09 (Table 4). The yield was evaluated by applying the standard agronomic practices from the date of sowing to harvest.

\section{Seed rate trial}

This trial was conducted to optimize the seed rate of suhran-2012 for maximum yield. Three different seed rates 1,2 and $3 \mathrm{~kg}$ were used. This experiment was conducted under RCBD with three replications.

\section{Row spacing trial}

The purpose of this trial to maintain maximum plant population and production. There were three different row spacing used under RCB design with three replications. Three different row spacing $(15,30,45 \mathrm{~cm})$ were used in this experiment to optimize the maximum production.

\section{Date of sowing trial}

This trial was conducted to assess the maximum yield under three various sowing dates $\left(15^{\text {th }}\right.$ September, 1 st October and 15th October). Data of three different sowing dates was analyzed to optimize the maximum production of surhan-2012.

\section{Fertilizer yield trial}

This trial was conducted to optimize rate and application method of fertilizer for maximum production of surhan-2012. The combination of three levels of nitrogen, phosphorus and potassium were evaluated along with control under RCB design (Table 10). 
Table 1: General plant descriptor of mutant ROO$125 / 14$

\section{Traits}

\section{Description}

\section{Plant characteristics}

Plant Height

$177.3 \mathrm{~cm}$

Plant Type

Growth habit

Branching

Plant Colour

Seedling characteristics

Growth Habit

Seedling Length

Cotyledon Length

Cotyledon Width

Seedling Anthocyan

Leaf characteristics

Leaf Colour

Leaf Attitude

Leaf Size

Leaf Length

Leaf Width

Petiole Length

Petiole Base

Leaf Lobbing

Margin Indent

Terminal Segment

Leaf Hair

Leaf

Stem characteristics

$\begin{array}{ll}\text { Stem Shape } & \text { Round } \\ \text { Stem Thickness } & 16-20 \mathrm{~mm} \\ \text { Stem Stiffness } & \text { Medium } \\ \text { Stem Pith } & \text { Thick } \\ \text { Ramification } & \text { At low level }\end{array}$

Flower characteristics

Days to Flowering (50 \% flow- 77-80 days ering)

$\begin{array}{ll}\text { Earlier/Later than } & \begin{array}{l}\text { Earlier than Rainbow and } \\ \text { Wester }\end{array} \\ \begin{array}{l}\text { Duration } \\ \text { Petal Colour }\end{array} & 30-35 \\ \text { Anther Dotting } & \text { Yellow } \\ \text { Pollination } & \text { Absent } \\ \text { Silique characteristics } & \text { Self } \\ \text { Pod Shape } & \text { Cylindrical } \\ \text { Pod Anthocyan } & \text { Absent } \\ \text { Pod Attitude } & \text { Erect } \\ \text { Pod Density } & \text { Heavy }\end{array}$

$\begin{array}{ll}\text { Pod Length } & 82 \mathrm{~mm}, \\ \text { Pod Width } & 6.1 \mathrm{~mm} \\ \text { Pedical Length } & 18 \mathrm{~mm}, \\ \text { Beak Length } & 15 \mathrm{~mm}, \\ \text { Shattering } & \text { Low } \\ \text { Seeds/Pod } & 30-35\end{array}$

Seed characteristics

$\begin{array}{ll}\text { Seed Colour } & \text { Dark brown } \\ \text { Seed Size } & \text { Bold } \\ \text { Seed weight } & 2.9-4.0 \mathrm{mg} / \mathrm{seed} \\ \text { Seed Yield Potential } & 2000 \mathrm{~kg} / \mathrm{ha} \\ \text { Oil Content } & 45 \% \\ \text { Lenolenic acid } & 18.5 \% \\ \text { Lenoleic acid } & 15.30 \% \\ \text { Oleic acid } & 66.3 \% \\ \text { Resistant } & \\ \text { Lodging } & \text { Tolerant } \\ \text { Mildew (Personospora parasit- } & \text { Resistant } \\ \text { ica) } & \\ \text { Aphids } & \text { Tolerant }\end{array}$

\section{Pest and disease incidence}

The infestation data of various biotic diseases were recorded after the 15 days intervals in NURYT at the nuclear institute of Agriculture during 2006-08. The yield performance of candidate strain (R00-125/14) was evaluated and compared with the parent variety and local check Shiralee.

\section{Statistical analysis}

The statistics analysis of variance of each measuring traits was performed by using appropriate procedure of statistical package MSTAT-C. Differences among means were tested by the least significant difference test at 5 percent probability level.

\section{Results and Discussion}

\section{Determination of Agronomic and quality related parameters}

R00-125/14 plants have mostly round and thick stem, the average plant height is $177.3 \mathrm{~cm}$ with determinate, spreading and branchy growth habit and earlier flowering than rainbow and wester varieties. Silique is cylindrical and filled with $18-20$ seeds and seeds are dark brown, bold with average $45 \%$ oil content and may also be used for edible purpose. R00125/14 seeds have oleic acid (66.3\%), lenoleic acid $(15.30 \%)$ and lenolenic acid (18.5\%). Siliqua length 
of R00-125/14 ranging from 80 to $85 \mathrm{~mm}$ in length and 5.3 to $6.5 \mathrm{~mm}$ in width along with average of 19 seeds siliqua ${ }^{-1}$. The overall usual seed yield potential of $\mathrm{R} 00-125 / 14$ is $2000 \mathrm{~kg} \mathrm{ha}^{-1}$ (Table 1 ).

R00-125/14 is high yield and bold seeded new variety having good yield performance. This mutant stain contains low erucic acid ( $0.76 \%)$ and glucosinolates ( $27.81 \mu$ mole $/ \mathrm{g})$ contents. This mutant show high oil contents $(42.90 \%)$, compared to local check and parents. The morphological and botanical characteristics also recorded for this variety (Table 1). R00-125/14 variety is most popular in the Sindh province due to good oil content and yield. R00-125/14 is required short duration to complete vegetative and reproductive cycle and give high yield as compared to local check and parents. The short duration variety encourages the farmers to expand on a large area.

\section{Initial varietal evaluation trials}

Seed of Rainbow were treated with doses $(750,1000$ and $1250 \mathrm{~Gy}$ ) of gamma rays and irradiated material were grown at the experimental farm of Nuclear Institute of Agriculture (NIA) Tando Jam. In this trial eighteen mutants were selected for further evaluation. The mutant with high seed yield with remarkable high oil contents. Mutant R00-125/14 produced the highest seed yield $(1575 \mathrm{~kg} / \mathrm{ha})$ and oil content (45.66\%) as compared to all other entries. The mutant stain (R00-125/14) produced high 1000 seed weight (g) and oil content as compared to the parents. Besides the promising potential for seed and oil yield, this mutant also exhibited good growth habit. Erectness and non-shattering plants are some of attractive features in brassica because shattering, adversely reduces (30-40 \%) seed yield.

\section{Preliminary yield trial}

Nine mutants were selected along with parents and check variety for evaluation in preliminary yield trial at experimental farm, NIA, Tandojam during 200304 . The mutant R00-125/14 produced the highest seed yield (1859 kg/ha) and oil (43.20 \%) followed by R00-125/16 (1348 kg/ha); whereas parent (Rainbow) produces low (493 kg/ha) seed yield and oil content $(39.50 \%)$ which is significantly less as compare to mutant R00-125/14. This mutant not only produced the highest seed yield but also high oil contents per unit area. It exhibited increased 1000 seed weight, seed yield and oil contents as compared to Rainbow and Wester, respectively (Table 2).
Table 2: Performance of mutant (SUHRAN-2012) in preliminary yield trial of rainbow \& westar.

$\begin{array}{llllll}\text { Varieties } & \begin{array}{l}\text { Maturity } \\ \text { (days) }\end{array} & \begin{array}{l}\text { Plant } \\ \text { Height } \\ \text { (cm) }\end{array} & \begin{array}{l}\mathbf{1 0 0 0} \\ \text { Seed } \\ \text { Wt. (g) }\end{array} & \begin{array}{l}\text { Seed } \\ \text { Yield } \\ \text { Kg/ha }\end{array} & \begin{array}{l}\text { Oil } \\ \text { Con- } \\ \text { tent \% }\end{array} \\ \text { Rainbow(P) } & 135.0 \mathrm{~b} & 170.53 \mathrm{~b} & 3.94 \mathrm{e} & 800.0 \mathrm{~h} & 42.0 \mathrm{~d} \\ \text { ROO-75/2 } & 131.0 \mathrm{c} & 138.53 \mathrm{e} & 4.34 \mathrm{ab} & 708.0 \mathrm{~h} & 44.0 \mathrm{~b} \\ \text { ROO-100/5 } & 130.5 \mathrm{~cd} & 141.70 \mathrm{~d} & 4.19 \mathrm{c} & 650.0 \mathrm{j} & 41.66 \mathrm{~d} \\ \text { ROO-100/8 } & 122.0 \mathrm{~h} & 136.20 \mathrm{f} & 3.99 \mathrm{e} & 761.2 \mathrm{i} & 41.66 \mathrm{~d} \\ \text { ROO-100/9 } & 120.0 \mathrm{i} & 135.33 \mathrm{~g} & 4.17 \mathrm{~cd} & 880.0 \mathrm{~g} & 42.33 \mathrm{c} \\ \text { ROO-100/10 } & 122.5 \mathrm{gh} & 146.60 \mathrm{c} & 4.10 \mathrm{~d} & 982.2 \mathrm{f} & 42.33 \mathrm{c} \\ \text { ROO100/11 } & 126.3 \mathrm{f} & 137.60 \mathrm{~d} & 4.22 \mathrm{bc} & 1050.6 \mathrm{e} & 44.0 \mathrm{~b} \\ \text { ROO-125/12 } & 127.5 \mathrm{e} & 134.90 \mathrm{~h} & 4.23 \mathrm{bc} & 1205.3 \mathrm{~cd} & 41.0 \mathrm{ef} \\ \text { ROO-125/13 } & 129.6 \mathrm{~d} & 145.50 \mathrm{~cd} & 4.26 \mathrm{~b} & 1318.6 \mathrm{~b} & 42.33 \mathrm{c} \\ \text { ROO-125/14 } & 124.5 \mathrm{~g} & 133.40 \mathrm{i} & 4.75 \mathrm{a} & 1460.8 \mathrm{a} & 45.0 \mathrm{a} \\ \text { Pakola(C) } & 181.5 \mathrm{a} & 178.00 \mathrm{a} & 3.74 \mathrm{f} & 1254.1 \mathrm{c} & 40.33 \mathrm{f}\end{array}$

\section{Station yield trial}

The yield performance of four mutants with parents and two checks (Bulbul and Pakola) were evaluated at Experimental Farm, NIA, Tando Jam in Station Yield Trial. The performance of mutant R00-125/14 $(1608.4 \mathrm{~kg} / \mathrm{ha})$ was better than rainbow parent (1259.0 kg/ha) and both check bulbul $(982.2 \mathrm{~kg} / \mathrm{ha})$ and pakola $(1545.0 \mathrm{~kg} / \mathrm{ha})$ which are depicted in $\mathbf{T a -}$ ble 3 .

Table 3: Performance of mutant (R00-125/14) in station yield trial of rainbow E $\sigma^{2}$ westar.

\begin{tabular}{llllll} 
Varieties & $\begin{array}{l}\text { Maturity } \\
\text { (days) }\end{array}$ & $\begin{array}{l}\text { Plant } \\
\text { Height } \\
\text { (cm) }\end{array}$ & $\begin{array}{l}\text { Se00 } \\
\text { Wt. (g) }\end{array}$ & $\begin{array}{l}\text { Seed } \\
\text { Yield } \\
\text { Kg/ha }\end{array}$ & $\begin{array}{l}\text { Oil } \\
\text { Content } \\
\text { \% }\end{array}$ \\
\hline R00-75/1 & $116.0 \mathrm{~g}$ & $126.2 \mathrm{f}$ & $4.63 \mathrm{bc}$ & $1005.7 \mathrm{f}$ & $44.16 \mathrm{bc}$ \\
R00-125/12 & $131.0 \mathrm{~d}$ & $149.0 \mathrm{~d}$ & $4.83 \mathrm{a}$ & $1058.1 \mathrm{e}$ & $44.3 \mathrm{~b}$ \\
R00-125/14 & $124.0 \mathrm{f}$ & $160.0 \mathrm{c}$ & $4.82 \mathrm{a}$ & $1608.4 \mathrm{a}$ & $45.0 \mathrm{a}$ \\
R00-125/17 & $126.3 \mathrm{e}$ & $146.0 \mathrm{e}$ & $4.77 \mathrm{~b}$ & $1161.1 \mathrm{~d}$ & $44.8 \mathrm{ab}$ \\
Rainbow(P) & $138.0 \mathrm{c}$ & $146.0 \mathrm{e}$ & $3.86 \mathrm{~cd}$ & $1259.0 \mathrm{c}$ & $44.0 \mathrm{c}$ \\
Bulbul(C) & $181.0 \mathrm{~b}$ & $178.5 \mathrm{a}$ & $3.95 \mathrm{c}$ & $982.2 \mathrm{~g}$ & $40.16 \mathrm{de}$ \\
Pakola(C) & $185.0 \mathrm{a}$ & $165.5 \mathrm{~b}$ & $3.50 \mathrm{~d}$ & $1545.0 \mathrm{~b}$ & $40.50 \mathrm{~d}$
\end{tabular}

\section{Advanced yield trial}

The four mutants along with Rainbow parent and two checks (Bulbul and Pakola) were evaluated in Advanced Yield Trial at Experimental Farm, NIA, Tando Jam during 2005-06 (Table 4). The mutant R00$125 / 14$ produced the highest seed yield $(1998 \mathrm{~kg} / \mathrm{ha})$ and oil content (44.8\%). It also showed higher 1000 seed weight $(4.90 \mathrm{~g})$ as compared to Rainbow parent $(1403.0 \mathrm{~kg} / \mathrm{ha})$ and local check Wester $(1357.0 \mathrm{~kg} /$ ha). 
Table 4: Performance of mutant (R00-125/14) in advanced yield trial of Rainbow E Westar during 2005-06.

\begin{tabular}{llllll} 
Varieties & $\begin{array}{l}\text { Matu- } \\
\text { rity } \\
\text { (days) }\end{array}$ & $\begin{array}{l}\text { Plant } \\
\text { Height } \\
\text { (cm) }\end{array}$ & $\begin{array}{l}\text { 1000 } \\
\text { Seed } \\
\text { Wt. }(g)\end{array}$ & $\begin{array}{l}\text { Seed } \\
\text { Yield } \\
\text { Kg/ha }\end{array}$ & $\begin{array}{l}\text { Oil Con- } \\
\text { tent \% }\end{array}$ \\
R00-75/1 & $111.6 \mathrm{~g}$ & $137.6 \mathrm{~g}$ & $4.20 \mathrm{c}$ & $1038.0 \mathrm{~g}$ & $40.0 \mathrm{~d}$ \\
$\mathrm{R} 00-125 / 12$ & $122.3 \mathrm{f}$ & $169.3 \mathrm{c}$ & $4.53 \mathrm{~b}$ & $1884.0 \mathrm{~b}$ & $43.0 \mathrm{~b}$ \\
$\mathrm{R} 00-125 / 14$ & $124.6 \mathrm{e}$ & $158.6 \mathrm{f}$ & $4.90 \mathrm{a}$ & $1998.0 \mathrm{a}$ & $44.80 \mathrm{a}$ \\
R00-125/17 & $126.3 \mathrm{~d}$ & $168.6 \mathrm{~d}$ & $4.93 \mathrm{a}$ & $1806.0 \mathrm{c}$ & $40.20 \mathrm{c}$ \\
Rainbow(P) & $133.3 \mathrm{c}$ & $175.6 \mathrm{~b}$ & $3.80 \mathrm{f}$ & $1403.0 \mathrm{e}$ & $39.70 \mathrm{e}$ \\
Bulbul(C) & $138.6 \mathrm{~b}$ & $167.3 \mathrm{e}$ & $4.00 \mathrm{~d}$ & $1357.0 \mathrm{f}$ & $39.01 \mathrm{f}$ \\
Pakola(C) & $184.5 \mathrm{a}$ & $177.5 \mathrm{a}$ & $3.98 \mathrm{e}$ & $1625.5 \mathrm{~d}$ & $39.50 \mathrm{ef}$ \\
\hline
\end{tabular}

\section{Zonal yield trial}

The performance of canola mutant (R00-125/14) along with parent (Rainbow) and local check (Wester and Pakola) were evaluated in zonal yield trial at seven different locations viz. Tando Jam, Sheikh Burkhio, Tando Adam, Sanghar, Khipro and Badin during 2007-08. The mutant R00-125/14 produced the highest seed yield at all the locations and showed $30.39,12.68,42.31$ and $9.80 \%$ increase in Rainbow at all locations respectively (Table 5).

National uniform rapeseed yield trial (NURYT)

National uniform yield trails of promising mutant R00-125/14 and other entries including Shiralee as a check were conducted on eight different ecological zones throughout the country under auspicious of NARC, Islamabad during 2007-08 and 2008-09. The mutant stain (R00-125/14) showed promising performance and attained $3^{\text {rd }}$ position at national level and produced average seed yield $1813 \mathrm{~kg} / \mathrm{ha}$ and exhibited $4.25 \%$ increase over Shiralee. Whereas in Sindh province at Tando Jam and Khairpur, R00$125 / 14$ showed $10.96 \%$ and $30.48 \%$ increase from both check shiralee and Hyola -42 (Table 6a and 6b).

\section{Seed rate trial}

The yield performance of mutant R00125/14 was assessed in seed rate trials during 2007-08 and 200809. The highest seed yield (1910 kg per acre) was recorded in treatment $T_{2}$ followed by treatments $\mathrm{T}_{3}$ (1855 kg per acre) which depicted in Table 7. Lowest seed yield was recorded in $\mathrm{T}_{1}$. Essence of

Table 5: Mean yield performance of R00-125/14 in zonal varietal trial during 2007-09.

$\begin{array}{llllllll}\text { Genotypes } & \text { Tando Jam } & \text { Shaikh Burkhio } & \text { Tando Adam } & \text { Sanghar } & \text { Khipro } & \text { Shaikh Burkhio } & \text { Badin (Golarchi) } \\ \text { R00-75/1 } & 1011.0 \mathrm{~d} & 992.3 \mathrm{c} & 1231.0 \mathrm{~b} & 940.5 \mathrm{c} & 1356 \mathrm{~b} & 1466 \mathrm{~b} & 1245 \mathrm{c} \\ \text { R00-125/14 } & 1371.0 \mathrm{a} & 1132.5 \mathrm{a} & 1278.0 \mathrm{a} & 1053.5 \mathrm{a} & 2353 \mathrm{a} & 2233 \mathrm{a} & 2026 \mathrm{a} \\ \text { Rainbow(p) } & 1051.4 \mathrm{c} & 1005.0 \mathrm{~b} & 898.0 \mathrm{e} & 959.4 \mathrm{~b} & 1243 \mathrm{~cd} & 1433 \mathrm{~cd} & 1136 \mathrm{e} \\ \text { Westar(C) } & 987.5 \mathrm{e} & 784.4 \mathrm{~d} & 1022.5 \mathrm{c} & 849.3 \mathrm{~d} & 1246 \mathrm{c} & 1454 \mathrm{c} & 1326 \mathrm{~b} \\ \text { Pakola(C) } & 1182.2 \mathrm{~b} & 695.6 \mathrm{e} & 924.8 \mathrm{~d} & 675.3 \mathrm{e} & 1084 \mathrm{de} & 1065 \mathrm{~d} & 1148 \mathrm{~d}\end{array}$

Table 6a: Performance of R00-125/14 in NURYT at Eight Locations during 2007-08.

$\begin{array}{llllllllll}\text { Entries } & \text { NARC } & \text { CHK } & \text { FSD } & \text { KPUR } & \text { BWP } & \text { NIFA } & \text { Kohat } & \text { T.Jam } & \text { Mean } \\ \text { R00-75/1 } & 2826 & 792 & 1118 & 1511 & 1243 & 1729 & 1517 & 1417 & 1519 \\ \text { R00-125/14 } & 2628 & 1444 & 1428 & 1511 & 2050 & 1729 & 1417 & 2333 & 1818 \\ \text { Hyola-42 } & 2638 & 847 & 1250 & 1470 & 903 & 1917 & 500 & 1317 & 1355 \\ \text { Shiralee(C) } & 2788 & 729 & 1123 & 1158 & 1414 & 1896 & 1271 & 1277 & 1457 \\ \text { 97-5/2-4 } & 2551 & 903 & 1313 & 1563 & 1462 & 2354 & 1742 & 1234 & 1640 \\ \text { LSD(0.05) } & 278.2 & 181.3 & 204 & 302.5 & 51.9 & 307.6 & 313.0 & 104.3 & -\end{array}$

Table 6b: Performance of R00-125/14 in NURYT at Eight Locations during 2008-09.

$\begin{array}{llllllllll}\text { Entry Name } & \text { NARC } & \text { CHK } & \text { FSD } & \text { B-PUR } & \text { K-PUR } & \text { Pioneer } & \text { NIFA } & \text { DIK } & \text { Mean } \\ \text { R00-75/1 } & 2135 & 1264 & 1285 & 1370 & 1246 & 1600 & 1375 & 1917 & 1524 \\ \text { R00-125/14 } & 2227 & 1444 & 1428 & 2050 & 1229 & 1759 & 1562 & 2333 & 1754 \\ \text { Hyola-42 } & 2809 & 2006 & 1377 & 1834 & 333 & 1944 & 2292 & 2208 & 1850 \\ \text { Shiralee(C) } & 2052 & 1588 & 1948 & 2111 & 979 & 2001 & 1604 & 2083 & 1796 \\ \text { 97-5/2-4 } & 2582 & 1799 & 1764 & 1363 & 696 & 1329 & 2688 & 2167 & 1798 \\ \text { LCD (0.05) } & 386 & 139 & 146 & 319 & 272 & 576 & 599 & 530 & 172\end{array}$


application of proper seed rate was evident from the lowest seed yield in $T_{1}$ where low seed rate was practiced. The seed yield difference among the treatments $\mathrm{T}_{2}$ and $\mathrm{T}_{3}$ was less than $5 \%$. Yield differences was negligible reflect its impact on the economic benefit. As per cost benefit ratio, it was observed that $2 \mathrm{~kg}$ per acre was suitable seed rate for seed yield.

Table 7: Seed rate trial at NIA, Tando Jam during 2007-09.

$\begin{array}{rllllll}\text { Genotypes } & \begin{array}{l}\text { Seed } \\ \text { Rate }\end{array} & \begin{array}{l}\text { Maturity } \\ \text { (days) }\end{array} & \begin{array}{l}\text { Plant } \\ \text { Height } \\ \text { (cm) }\end{array} & \begin{array}{l}\text { Seed } \\ \text { Wt. (g) }\end{array} & \begin{array}{l}\text { Seed } \\ \text { Yield } \\ \text { Kg/ha }\end{array} & \begin{array}{l}\text { Oil } \\ \text { Content } \\ \text { \% }\end{array} \\ \text { R00-125/14 } & 1 \mathrm{~kg} & 131 & 143 & 4.45 & 1247 & 41.2 \\ 2 \mathrm{~kg} & 129 & 154 & 4.76 & 1910 & 41.9 \\ 3 \mathrm{~kg} & 134 & 165 & 4.54 & 1855 & 41.7\end{array}$

\section{Row spacing trial}

The yield performance of mutant R00125/14 was evaluated in row spacing trials during 2007-08 and 2008-09. The highest seed yield (1898 kg/ha) was recorded at $30 \mathrm{~cm}$ row spacing followed by $45 \mathrm{~cm}(1867$ $\mathrm{kg} / \mathrm{ha}$ while lowest seed yield was observed at $15 \mathrm{~cm}$ row spacing. The proper row spacing is required by the plant for its nourishment and growth. As per cost benefit ratio, it was observed that $30 \mathrm{~cm}$ row spacing was most suitable strategy for seed yield (Table 8).

Table 8: Row spacing trial at NIA, Tando Jam during 2007-09.

\begin{tabular}{|c|c|c|c|c|c|c|}
\hline Genotypes & Spacing & $\begin{array}{l}\text { Maturity } \\
\text { (days) }\end{array}$ & $\begin{array}{l}\text { Plant } \\
\text { Height } \\
\text { (cm) }\end{array}$ & $\begin{array}{l}1000 \\
\text { Seed } \\
\text { Wt. (g) }\end{array}$ & $\begin{array}{l}\text { Seed } \\
\text { Yield } \\
\mathrm{Kg} / \mathrm{ha}\end{array}$ & $\begin{array}{l}\text { Oil Con- } \\
\text { tent } \%\end{array}$ \\
\hline \multirow{3}{*}{$\begin{array}{l}\text { R00- } \\
125 / 14\end{array}$} & $15 \mathrm{~cm}$ & 127 & 147 & 4.65 & 1734 & 41.3 \\
\hline & $30 \mathrm{~cm}$ & 123 & 158 & 4.70 & 1898 & 41.8 \\
\hline & $45 \mathrm{~cm}$ & 125 & 162 & 4.82 & 1867 & 41.5 \\
\hline
\end{tabular}

\section{Date of sowing trial}

Data showed that the yield performance of mutant R00-125/14 was assessed under various sowing dates. The highest seed yield $(2455 \mathrm{~kg} / \mathrm{ha})$ was recorded at sowing date 1 st October followed by 15 th September $(2339 \mathrm{~kg} / \mathrm{ha})$ sowing date. The recommended sowing date according to the current series of trials of mutant R00-125/14 is 1st week of October (Table 9).

\section{Fertilizer trial}

The yield performance of R00-125/14 was assessed under various levels of fertilizer doses. The highest seed yield (2321 kg ha-1) was recorded in treatment (6) followed by treatments (5) (2245 kg ha $\left.{ }^{-1}\right)$ which depicted in Table 10 and lowest seed yield was re- corded in control. The essence application of NPK fertilizers in our soil was evident compared to the lowest seed yield under control where no fertilization was practiced. The yield difference among the treatments $\mathrm{T}_{5}$ and $\mathrm{T}_{6}$ was less than $5 \%$. As per cost benefit ratio, it was observed that treatment $T_{5}$ was suitable fertilizer treatment for seed yield.

Table 9: Yield performance in date of sowing trial.

\begin{tabular}{|c|c|c|c|}
\hline \multirow[t]{2}{*}{ Sowing Date } & \multicolumn{2}{|c|}{ Yield (kg/ha) } & \multirow[t]{2}{*}{ Av. (kg/ha) } \\
\hline & $2007-08$ & 2008-09 & \\
\hline $15^{\text {th }}$ September & 2539 & 2138 & 2339 \\
\hline Ist October & 2301 & 2608 & 2455 \\
\hline $15^{\text {th }}$ October & 2013 & 1714 & 1864 \\
\hline Ist November & 1468 & 1534 & 1501 \\
\hline 15 th November & 1210 & 1217 & 1214 \\
\hline LSD $5 \%$ & 76 & 105 & \\
\hline
\end{tabular}

Table 10: Yield response to different fertilizer levels.

\begin{tabular}{|c|c|c|c|c|}
\hline $\begin{array}{l}\text { Treat- } \\
\text { ment }\end{array}$ & $\begin{array}{l}\text { Nitrogen } \\
\text { (kg/ha) }\end{array}$ & $\begin{array}{l}\text { Phosphorus } \\
\text { P2O5 }(\mathbf{k g} / \mathbf{h a})\end{array}$ & $\begin{array}{l}\text { Potash K2O } \\
(\mathrm{kg} / \mathrm{ha})\end{array}$ & $\begin{array}{l}\text { Seed Yield } \\
(\mathrm{kg} / \mathrm{ha})\end{array}$ \\
\hline 1 & 00 & 00 & 00 & 1459 \\
\hline 2 & 75 & 75 & 00 & 2074 \\
\hline 3 & 75 & 75 & 30 & 2209 \\
\hline 4 & 75 & 75 & 60 & 2029 \\
\hline 5 & 75 & 75 & 90 & 2245 \\
\hline 6 & 100 & 90 & 00 & 2321 \\
\hline 7 & 100 & 90 & 30 & 2146 \\
\hline 8 & 100 & 90 & 60 & 2074 \\
\hline 9 & 100 & 90 & 90 & 2123 \\
\hline \multicolumn{4}{|c|}{ LSD 5\% } & 230 \\
\hline
\end{tabular}

Biotic stress studies

R00-125/14 and thirty other canola genotypes were evaluated against insect pests and other pathological diseases (Alternaria Blight, Powdery Mildew, Downy Mildew and White Rust) at Experimental Farm, NIA, Tando Jam under open field and laboratory conditions. The data showed that the candidate variety was highly resistant as compared to other canola genotypes which are depicted in Table 11 and 12.

R00-125/14 is referred to as short height mutant which is lodging resistant in response to unfavorable weather conditions, and high responsive to fertilizers to attain primary goal of high seed yield. Furthermore, the short height (dwarfness) positively correlated to early maturity. The early maturity is desirable character of crops especially canola (Hu et al., 2017). 
Table 11: Aphid (\%) infested plant in mutant along with parent and check at 5 ecological zone of Sindh Province.

$\begin{array}{llllllll}\text { Genotypes } & \text { Tando Jam } & \text { Shaikh Burkhio } & \text { Tando Adam } & \text { Sanghar } & \text { Khipro } & \text { Shaikh Burkhio } & \text { Badin } \\ \text { Wester } & 14.5 & 15.6 & 13.5 & 10.8 & 12.6 & 13.6 & 13.6 \\ \text { R00-125/14 } & 8.2 & 9.4 & 6.4 & 4.3 & 7.5 & 4.3 & 6.8 \\ \text { Rainbow(p) } & 9.6 & 10.3 & 7.9 & 12.5 & 14.6 & 12.4 & 9.7 \\ \text { Oscar } & 11.3 & 9.8 & 8.3 & 13.4 & 12.4 & 11.3 & 12.6 \\ \text { Pakola(C) } & 10.4 & 12.4 & 11.4 & 10.9 & 15.6 & 13.6 & 10.7 \\ \text { Shirale } & 12.17 & 10.13 & 9.5 & 8.5 & 14.7 & 12.3 & 11.3\end{array}$

Table 12: Disease response of SUHRAN-2012.

$\begin{array}{lllll}\text { Genotypes } & \begin{array}{l}\text { Alternaria } \\ \text { Blight (0-9)* }\end{array} & \begin{array}{l}\text { Powdery } \\ \text { Mildew(\%) }\end{array} & \begin{array}{l}\text { Downy } \\ \text { Mildew(\%) }\end{array} & \begin{array}{l}\text { White } \\ \text { Rust (\%) }\end{array} \\ \text { Wester } & 3 & 2 & 1 & 1 \\ \text { R00-125/14 } & 2 & 0 & 0 & 0 \\ \text { Rainbow(p) } & 3 & 4 & 2 & 3 \\ \text { Oscar } & 5 & 0 & 1 & 3 \\ \text { Pakola(C) } & 3 & 4 & 2 & 1 \\ \text { Shirale } & 3 & 0 & 0 & 0\end{array}$

The short statured mutants were selected from the rapeseed and mustard population which is treated with physical mutagen (Javed et al., 2003). R00$125 / 14$ mutant results are in accordance with this study and also confirmed positive impact of induced mutation (Gamma radiation).

Breeding for enhancement of seed yield significantly correlated to genetically improve new genotypes with accumulation of desirable and high yielding genes. The siliqua per plant, number of seed per siliqua and 1000 seed weight are the significant factors responsible to enhance the productivity of oil seed crops (Barve et al., 2009). R00-125/14 was selected from mutagen treated population which produced higher number of siliqua per plant, seed per siliqua and 1000 seed weight as compared to mother variety (Landge et al., 2009). The pervious researchers also reported that mutant selected from mutagen treated population which has high seed yield and oil contents in rapeseed and mustard than the mother variety (Channaoui et al., 2019). R00-125/14 mutant exhibited large size and high seed per siliqua related to high yield. Early maturity is very important character in many crops including rapeseed and mustard which is the outcome of mutation breeding (Malek et al., 2014). Many early matured mutants varieties have been reported in oilseed crops Brassica (Kumawat et al., 2019), which is reliable in accordance to the season and demand of the farmers. The R00-125/14 mutant showed sig- nificantly high yield and oil contents with respect to check and mother variety during early station trial. The high 1000 seed weight was the actual cause of high yield in this variety (Ray et al., 2019; Viana et al., 2019).

Powdery mildew is a serious disease of canola which predominantly affects the mid-season and late mid-season canola crop especially at the seed development stage. The disease screening against the powdery mildew (Erysiphe polygoni) was made in the open field and was found moderately resistant. The same screening method of powdery mildew was already reported in previous research (Nanjundan et al., 2020). Their level of tolerance against this disease was also reported by (Azmat et al., 2020). The level of tolerance/resistance is defined through the genetics. The level of resistance against these two diseases was justified by the low rate of plant mortality (11-25\%) effecting the mutant (R00-125/14).

No, serious insect/pest on the mutant R00-125/14 was recorded. Only minute attacks of aphid per plant per leaf were noticed on R00-125/14 which can be easily controlled or overcome through suitable insecticide dosage. The characteristics of a cultivar along with a combination of traits differ according to the varying climatic conditions at different localities (Raza et al., 2019). Not only the environment played a vital role in the performance of the mutant (R00$125 / 14$ ) in diverse ecological zones of the country but at the same time the role of genetics cannot be over looked.

Sowing date trials were conducted to optimize sowing season and harvest maximum yield potential (Andarzian et al., 2015). Previous research findings are in consistent with the R00-125/14 which perform well when sown first week of October. The highest yield was recorded at $30 \mathrm{~cm}$ row spacing and similar finding also has been reported (Birhanu et al., 2018). 
113: 1198-1206. https://doi.org/10.1002/ ejlt.201100063

It is concluded that R00-125/14 performed better in all the yield trials as compared to other existing varieties (check and parent). The mutant stain showed maximum yield potential $1813 \mathrm{~kg} / \mathrm{ha}$ as compared to other existing mutant lines (R00-75/1, R00-125/12 and R00-125/17) during 2007-08 and 2008-09. The newly developed mutant strain showed higher seed yield (1998.0 kg/ha) advanced yield trial as compare to check (Bulbul and Pakola) and rainbow parent (1403 $\mathrm{kg} / \mathrm{ha}$ ). It was also insect pest and disease including Alternaria blight, powdery mildew, downy mildew and white rust tolerance. The agronomic study suggested that this mutant strain (R00-125/14) is most suitable in the existed cropping system and agronomic package of technology.

\section{Novelty Statement}

The current study conducted to selection and consequently development one of the first canola variety named as surhan-2012 for commercial cultivation in Sindh province of Pakistan. This variety possesses good agronomic characters as compared with locally adapted cultivars.

\section{Author's Contribution}

Mohammad Aquil Siddiqui: Conceived the idea, statistical analysis of the data and supervised the experiment.

Muhammad Mahran Aslam: Conducted the study, collected data and wrote first draft of manuscript.

Mahboob Ali Sial and Nighat Seema Soomro: Improved the manuscript through revisions and provide technical inputs.

\section{Muhammad Tahir Khan, Shafquat Yasmeen and}

Shumaila Sial: Helped in collecting the agronomic data of the crop.

Imtiaz Ahmad Khan: Provided technical inputs, proofread the work.

\section{Conflict of interest}

The authors have declared no conflict of interest.

\section{Reference}

Abbadi, A. and Leckband, G. 2011. Rapeseed breeding for oil content, quality, and sustainability. Eur. J. Lipid Sci. Technol.

Andarzian, B., Hoogenboom, G., Bannayan, M., Shirali,M.and Andarzian, B.2015.Determining optimum sowing date of wheat using CSMCERES-Wheat model. J. Saudi Soc. Agric. Sci. 14: 189-199. https://doi.org/10.1016/j. jssas.2014.04.004

Azmat, A., Yasmin, H., Hassan, M.N., Nosheen, A., Naz, R., Sajjad, M., Ilyas, N. and Akhtar, M.N.2020. Co-application of bio-fertilizer and salicylic acid improves growth, photosynthetic pigments and stress tolerance in wheat under drought stress. Peer. J. 8: e9960-e9960. https:// doi.org/10.7717/peerj.9960

Barve, Y.Y., Gupta, R.K., Bhadauria, S.S., Thakre, R.P. and Pawar, S.E. 2009. Induced Mutations for Development of B juncea Canola Quality Varieties Suitable for Indian Agro-climatic Conditions. FAO, Food and Agriculture Organization of the United Nations (FAO).

Birhanu, A., Tadesse, T. and Tadesse, D. 2018. Effect of inter- and intra-row spacing on yield and yield components of mung bean (Vigna radiata $\mathrm{L}$.) under rain-fed condition at Metema District, northwestern Ethiopia. Agric. Food Secur. 7: 84. https://doi.org/10.1186/s40066018-0234-9

Channaoui, S., Labhilili, M., Mouhib, M., Mazouz, H., El Fechtali, M. and Nabloussi, A. 2019. Development and evaluation of diverse promising rapeseed (Brassica napus L.) mutants using physical and chemical mutagens. OCL 26, 35. https://doi.org/10.1051/oc1/2019031

Mustafa, H.S., E.-u.-H., T. Mahmood, M. Aftab, F. Saddique and H.-u. Rehman. 2017. Quantitative and qualitative evaluation of rapeseed (Brassica napus L.) genotypes for the development of high yielding canola quality cultivars. Discovery, 53: 380-387.

Hatzig, S., Breuer, F., Nesi, N., Ducournau, S., Wagner, M.H., Leckband, G., Abbadi, A. and Snowdon, R.J. 2018. Hidden Effects of Seed Quality Breeding on Germination in Oilseed Rape (Brassica napus L.). Front. Plant Sci. 9. https://doi.org/10.3389/fpls.2018.00419

Hu, Q., Hua, W., Yin, Y., Zhang, X., Liu, L., Shi, J., Zhao, Y., Qin, L., Chen, C. and Wang, H. 2017. Rapeseed research and production in China. Crop J. 5: 127-135. https://doi.org/10.1016/j. cj.2016.06.005 
Javed, M.A., Siddiqui, M.A., Khan, M.K.R., Khatri, A., Khan, I.A., Dahar, N.A., Khanzada, M.H. and Khan, R. 2003. Development of high yielding mutants of Brassica campestris $\mathrm{L} \mathrm{cv}$ Toria selection through gamma rays irradiation. Asian J. Plant Sci. 2: 192-195. https://doi. org/10.3923/ajps.2003.192.195

Kumawat, S., Rana, N., Bansal, R., Vishwakarma, G., Mehetre, S.T., Das, B.K., Kumar, M., Yadav, S.K., Sonah, H., Sharma, T.R. and Deshmukh, R. 2019. Expanding Avenue of Fast Neutron Mediated Mutagenesis for Crop Improvement. Plants, 8: 164. https://doi.org/10.3390/ plants8060164

Landge, S.P., Thakre, R.P., Pawar, S.E., Barve, Y.Y., Gupta, R.K. and Bhadauria, S.S. 2009. Development of B napus Canola Quality Varieties Suitable for Indian Agro-climatic Conditions by Induced Mutations. FAO, Food and Agriculture Organization of the United Nations (FAO).

Mahmood, T., H.S.B.M., M.A., Q.A., Arif and A. Malik. 2019. Super Canola: Newly Developed High Yielding, Lodging and Drought Tolerant Double Zero Cultivar of Rapeseed (Brassica napus L.). Genet. Mol. Res. 18: 1-17.

Malek, M.A., Rafii, M.Y., Shahida Sharmin Afroz, M., Nath, U.K. and Mondal, M.M.A. 2014. Morphological Characterization and Assessment of Genetic Variability, Character Association, and Divergence in Soybean Mutants. Scient. World J. 968796. https://doi. org/10.1155/2014/968796

Nanjundan, J., Manjunatha, C., Radhamani, J.,
Thakur, A.K., Yadav, R., Kumar, A., Meena, M.L., Tyagi, R.K., Yadava, D.K. and Singh, D. 2020. Identification of New Source of Resistance to Powdery Mildew of Indian Mustard and Studying Its Inheritance. Plant Pathol.J. 36: 111-120. https://doi.org/10.5423/ PPJ.OA.07.2019.0205

Onemli, F. 2014. Fatty Acid Content of Seed at Different Development Stages in Canola on Different Soil Types with Low Organic Matter. Plant Prod. Sci. 17: 253-259. https://doi. org/10.1626/pps.17.253

Ray, D.K., West, P.C., Clark, M., Gerber, J.S., Prishchepov, A.V. and Chatterjee, S. 2019. Climate change has likely already affected global food production. PLOS ONE. 14: e0217148. https://doi.org/10.1371/journal.pone.0217148

Raza, A., Razzaq, A., Mehmood, S.S., Zou, X., Zhang, X., Lv, Y. and Xu, J. 2019. Impact of Climate Change on Crops Adaptation and Strategies to Tackle Its Outcome: A Review. Plants (Basel) 8: 34. https://doi.org/10.3390/ plants 8020034

Viana, V.E., Pegoraro, C., Busanello, C. and Costa de Oliveira, A. 2019. Mutagenesis in Rice: The Basis for Breeding a New Super Plant. Front. Plant Sci. 10. https://doi.org/10.3389/ fpls.2019.01326

von Hanstein, A.S., Lenzen, S. and Plötz, T. 2020. Toxicity of fatty acid profiles of popular edible oils in human EndoC- $\beta \mathrm{H} 1$ beta-cells. Nutri. Diab. 10: 5. https://doi.org/10.1038/s41387020-0108-7 